\title{
Intestinal Obstruction Secondary to Postoperative Peritoneal Adhesions: the Tolerability of the Conservative Treatment
}

\author{
Simona Bobic ${ }^{1}$, Dragos Davitoiu', Adrian Dorin Bordei², Florian Popa ${ }^{3}$
}

\begin{abstract}
Introduction: The present study aims to determine the mean duration of the conservative management that can be tolerated by the patients with intestinal obstruction secondary to the postoperative peritoneal adhesions, in order to postpone the surgical intervention. Material and method: The data of the patients with intestinal obstruction secondary to postoperative peritoneal adhesions were retrospectively collected and analysed. The number of readmissions, the type of the therapeutic management, the duration of the conservative treatment, the number of surgical reinterventions and the intraoperative aspect represented the studied variables. Results: 543 patients with intestinal obstruction secondary to postoperative peritoneal adhesions, admitted in the Surgical Department of "Sfântul Pantelimon" Emergency Hospital from Bucharest, Romania, between January 2014 and July 2018, were enrolled in the study. 233 patients underwent conservative treatment, 310 patients being surgically treated. The mean interval necessary for the monitoring of the patients non- operatively treated was 7 days, within a range of 2 to 14 days. For the surgically treated cases, the mean monitoring interval was 5 days, within a range of 1 to 14 days. Among the patients that underwent surgical treatment, there were 276 cases of adhesiolysis, 31 cases of intestinal resection with anastomosis and 3 cases of intestinal resection with terminal ileo- or colostomy. Conclusion: Under strict monitoring, a significant number of cases of intestinal obstruction secondary to postoperative peritoneal adhesions can, successfully, be treated using conservative management, within 7-10 days.
\end{abstract}

Keywords: obstruction, peritoneal adhesions, conservative treatment

\begin{abstract}
Introducere: Obiectivul prezentului studiu este de a evalua durata medie a managementului conservator, ce poate fi suportată de către pacienții cu ocluzie intestinală secundară aderențelor peritoneale, în scopul temporizării intervenției chirurgicale cu viză curativă. Material și metodă: Datele pacienților cu ocluzie intestinală secundară aderențelor peritoneale postoperatorii au fost colectate și evaluate retrospectiv. Variabilele urmărite au fost reprezentate de: numărul reinternărilor, tipul de management terapeutic la fiecare reinternare, durata tratamentului conservator, numărul de reintervenții chirurgicale și aspectul intraoperator. Rezultate: 543 de pacienți cu ocluzie intestinală secundară aderențelor peritoneale postoperatorii, internați în perioada ianuarie 2014 - iulie 2018, au fost incluși în prezentul studiu. 233 de pacienți au beneficiat doar de tratament conservator, 310 pacienți fiind supuși intervenției chirurgicale. Perioada de timp necesară monitorizării pacienților tratați conservator a fost cuprinsă în intervalul
\end{abstract}

1 Department of General Surgery, „Sfantul Pantelimon" Emergency Hospital, „Carol Davila" University of Medicine and Pharmacy, Bucharest, Romania

2 Department of General Surgery, "Sfantul Pantelimon"

Emergency Hospital, Bucharest, Romania

${ }^{3}$ Department of General Surgery, "Carol Davila" Clinical Hospital,

"Carol Davila" University of Medicine and Pharmacy, Bucharest, Romania
Corresponding author.

Simona Bobic, Department of General Surgery, „Sfantul

Pantelimon" Emergency Hospital, $1^{\text {st }}$ Floor, 340-342 Pantelimon Avenue, $2^{\text {nd }}$ District, Bucharest, Romania.

E-mail: simona.bobic@umfcd.ro / simona.bobic@yahoo.ca 
2-14 zile, cu o medie de 7 zile, pentru pacienții tratați chirurgical perioada medie de urmărire fiind de 1-14 zile, cu o medie de 5 zile. Dintre pacienții supuși intervenției chirurgicale, 276 au beneficiat de adezioliză, 31 de pacienți de rezecție intestinală cu anastomoză și 3 pacienți de rezecție intestinală cu ileo- sau colostomie terminală. Concluzii: Sub strictă monitorizare, un număr semnificativ de pacienți cu ocluzie intestinală secundară aderențelor peritoneale prezintă răspuns favorabil la tratamentul conservator, prin reluarea toleranței orale și a tranzitului intestinal într-un interval de timp de 7-10 zile.

Cuvinte cheie: ocluzie, aderențe, tratament conservator.

\section{INTRODUCTION}

Postoperative peritoneal adhesion syndrome represents the main cause for the intestinal obstruction in adults ${ }^{1,2}$.

Intestinal obstruction secondary to postoperative peritoneal adhesions may have a favourable evolution with total remission of the signs and symptoms, or, may determine lethal complications. The optimal therapeutic method, surgical or medical, still represents a subject of debate, the results of the recent studies being controversial. Some authors emphasize the importance of an early surgical treatment for all cases of intestinal obstruction secondary to adhesions, taking into consideration the severe complications that may occur during the preoperative interval ${ }^{3}$. There have been mentioned, in the medical literature, cases of intestinal obstruction secondary to peritoneal adhesions that presented total remission, spontaneously or after medical treatment, with no indication for surgery. The aim of the retrospective study is to determine the mean interval needed for safely and efficiently undergoing conservative management for the patients with intestinal obstruction secondary to postoperative peritoneal adhesions, and to evaluate the specific factors that may lead to the surgical intervention.

\section{MATERIAL AND METHOD}

Patients with intestinal occlusion secondary to peritoneal adhesions, hospitalized between January 2014 and July 2018 at the General Surgery Department of the "Sfântul Pantelimon" Emergency Clinical Hospital in Bucharest, Romania, were selected from the InfoWord database. Diagnostic criteria for intestinal occlusion secondary to peritoneal adhesions were: personal history of surgical intervention, clinical picture specific for intestinal occlusion (abdominal pain, abdominal distension, vomiting, absence of stool), radiological signs of intestinal occlusion and exclusion of other causes of intestinal occlusion by additional investigations (upper / lower digestive endoscopy, computed abdominal pel- vic tomography). For patients with a personal history of malignancy or suspicion of malignant pathology, complex examinations for the exclusion of this pathological entity, such as tumor markers, ultrasound and computed abdominal-pelvic tomography, have been performed.

Clinical or paraclinical features, such as fever, tachycardia, signs of peritoneal irritation, leukocytosis and hyperamylasemia, have been analyzed and included in the study. Progression and severity of intestinal occlusion have been closely monitored. The medical history, the pathology for which the initial surgery was performed, and the number of readmissions for intestinal obstruction, were evaluated. Data were also recorded on the time interval between initial surgery and the reintervention, the duration of each hospitalization and of the symptomatology, the type of management performed (medical or surgical), the location and degree of peritoneal adhesions in patients treated surgically, and the occurrence of complications.

The conservative management included the following: nihil per os, gastric and intestinal decompression by nasogastric and Faucher tube placement, hydroelectrolytic rebalancing and parenteral nutrition, antibiotherapy in the presence of leukocytosis and daily imaging monitoring (abdominal ultrasound and radiography).

\section{RESULTS}

543 patients with intestinal obstruction secondary to postoperative peritoneal adhesions, admitted between January 2014 and July 2018, were included in this study. 233 patients received only conservative treatment, 310 patients undergoing surgery. Of those treated surgically, there were 276 cases of adhesiolysis, 31 of intestinal resection with anastomosis and 3 cases of intestinal resection with ileo- or colostomy.

All patients were over 18 years old and under 93 years old. The female: male ratio was 1.13: 1, with 289 female patients and 254 male patients. 
Analyzing the data of the patients included in the conservative treatment group (233 cases) and of those from the surgical group (310 cases), information regarding the surgical history was collected. Thus, among the past surgical procedures of the 233 patients with conservative treatment, 62 classical appendectomy, 29 gynecological procedures, 38 intestinal resections for malignant pathology, 43 intestinal resections for benign pathology and 47 interventions for the treatment of parietal defects were identified; 14 patients were enrolled in a separate group that included lowfrequency interventions, such as subtotal gastrectomy, cholecystectomy or splenectomy (Table 1).

A comparative analysis was made, between the conservative treatment group and the patients treated surgically, regarding the clinical and paraclinical parameters (Table 2).

Taking into account the data outlined in Table 2, a lower percentage of clinico-paraclinical and imagistic changes was observed in the group of patients who responded succesfully to conservative treatment, suggesting a less complicated stage of intestinal obstruction in this study group.

The duration of the conservative management required for remission of the occlusive symptomatology, within the group of patients who benefited only from this type of treatment, was evaluated. Also, the duration of the conservative therapy that was attempted during the preoperative period and proved to be ineffective, requi- ring surgical interventions, was quantified (Table 3). Thus, the average duration of the conservative management in patients receiving only this type of treatment was 7.05 days, and in patients who needed surgical intervention, 5.13 days (Table 3).

The topography and the degree of the peritoneal adhesions could be estimated intraoperatively in surgically treated patients, using the score developed by Mazuji et al. (Table 4) ${ }^{4}$.

The complications recorded in the two groups were represented by the recurrence of the intestinal obstruction, in the conservatively treated group of patients, and by the postoperative wound infection, pleural effusion or atelectasis, fixed or open evisceration, anastomotic fistula, sepsis, pulmonary thromboembolism, acute myocardial infarction, and recurrence of intestinal obstruction secondary to peritoneal adhesions, in the surgically treated group of patients.

The total number of the intestinal obstruction recurrence was 871 , for the 543 patients, with a case from the surgically treated group who presented 8 surgical readmissions during the study period, the time interval between the initial procedure and the readmission varying from 14 days to approximately 20 years, and between the time of first admission in the study period and the re-entry period ranging between 10 days and 3 years.

The general mortality rate in the study population was $5,43 \%$, with 2 cases from the conservative treat-

Table 1. Types of initial surgical procedures in the study population

\begin{tabular}{|l|c|c|}
\hline Initial pathology/ laparotomy & $\begin{array}{c}\text { Conservative treatment group } \\
(\mathbf{N = 2 3 3 )}\end{array}$ & $\begin{array}{c}\text { Surgical treatment group } \\
(\mathbf{N}=\mathbf{3 1 0})\end{array}$ \\
\hline Appendectomy & 62 & 38 \\
\hline Gynaecological procedures & 29 & 90 \\
\hline Intestinal resections for malignant pathology & 38 & 82 \\
\hline Intestinal resections for benign pathology & 43 & 40 \\
\hline Surgery of the parietal defects & 47 & 49 \\
\hline Varia & 14 & 11 \\
\hline
\end{tabular}

Table 2. Clinical, paraclinical and imagistic variables in the study population

\begin{tabular}{|l|c|c|}
\hline Variables & $\begin{array}{c}\text { Conservative treatment group } \\
(\mathbf{N}=\mathbf{2 3 3})\end{array}$ & $\begin{array}{c}\text { Surgical treatment group } \\
(\mathbf{N}=\mathbf{3 1 0})\end{array}$ \\
\hline Peritoneal signs & 0 & 261 \\
\hline Fever $>38^{\circ} \mathrm{C}$ & 93 & 279 \\
\hline Tachycardia & 64 & 123 \\
\hline Leucocytosis $>11000 / \mathrm{mmc}$ & 75 & 258 \\
\hline Hyperamylasemia & 103 & 199 \\
\hline Azotate retention & 26 & 201 \\
\hline Radiologic signs & 79 & 294 \\
\hline
\end{tabular}


Simona Bobic et al.

Table 3. The mean duration of the non- operative treatment in the study population

\begin{tabular}{|c|c|c|}
\hline $\begin{array}{c}\text { The mean duration of the non-operative } \\
\text { treatment (days) }\end{array}$ & Conservative treatment group (N=233) & Surgical treatment group (N=310) \\
\hline 1 & 0 & 24 \\
\hline 2 & 18 & 57 \\
\hline 3 & 22 & 37 \\
\hline 4 & 15 & 52 \\
\hline 5 & 26 & 36 \\
\hline 6 & 28 & 31 \\
\hline 7 & 20 & 20 \\
\hline 8 & 23 & 16 \\
\hline 10 & 19 & 7 \\
\hline 11 & 24 & 6 \\
\hline 12 & 16 & \\
\hline 13 & 17 & \\
\hline 14 & 2 & \\
\hline
\end{tabular}

Table 4. The severity score of the peritoneal adhesions

\begin{tabular}{|c|l|c|}
\hline \multicolumn{1}{|c|}{ The Mazuji score } & $\begin{array}{c}\text { Conservative } \\
\text { treatment group } \\
(\mathbf{N = 3 1 0 )}\end{array}$ \\
\hline 0 & \multicolumn{1}{|c|}{ Description } & 0 \\
\hline 1 & Very small, irregular, rare adhesion & 0 \\
\hline 2 & $\begin{array}{l}\text { Easily separable, medium intensity } \\
\text { adhesion }\end{array}$ & 21 \\
\hline 3 & $\begin{array}{l}\text { Intense, non- easily separable adhe- } \\
\text { sion }\end{array}$ & 40 \\
\hline 4 & $\begin{array}{l}\text { Very intense, non-easily separable, } \\
\text { homogenous }\end{array}$ & 249 \\
\hline
\end{tabular}

ment group and 27 cases from the surgical treatment group (Figure 1).

\section{DISCUSSION}

In addition to the well-known and extensively studied negative consequences, the formation of the postoperative peritoneal adhesions may have positive effect, by isolating inflammatory processes, preventing the systemic dissemination. However, the postoperative peritoneal adhesion syndrome represents the main cause for the small bowel obstruction ${ }^{2}$.

Figure 1. The mortality rate in the study groups.

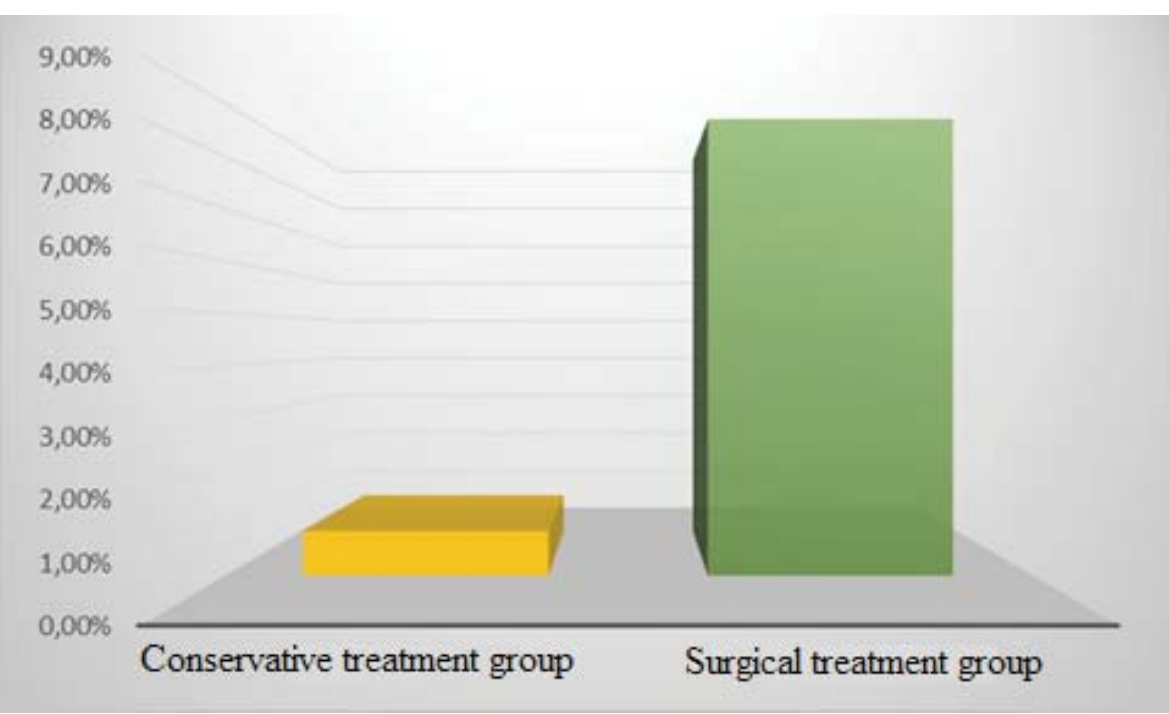


The intestinal obstruction occurs in approximately $10 \%$ of laparotomy patients with the onset of the symptomatology at any time after the initial intervention, being associated with a high rate of readmission ${ }^{5}$. The results of this study demonstrated a 2 weeks to 20 years interval between the initial laparotomy and the symptomatic onset of the intestinal occlusion.

Although intestinal obstruction secondary to postoperative peritoneal adhesions occurs after any type of abdominal or pelvic surgery, studies have shown a higher incidence following inferior abdominal or pelvic surgery ${ }^{3}$. In the present study, the surgical procedures frequently encountered in the personal medical history were: intestinal resections, gynecological interventions, and parietal defect repair.

There is a continuous debate regarding the optimal method of treatment in patients with intestinal obstruction secondary to postoperative peritoneal adhesions. The pathophysiological process of the intestinal obstruction is dynamic, occlusive episodes alternating with episodes of remission. Thus, there are still no predictive factors capable of making a clear distinction between the occlusive episodes that can be spontaneously resolved or medically treated and those requiring surgical intervention. There have been described, in the medical literature and in the studied population, cases of intestinal obstruction secondary to adhesions, with loop necrosis, in the absence of suggestive signs, such as fever, peritoneal signs, leukocytosis and azotate retention. This type of clinical scenario makes it difficult to establish the conservative management and to estimate the optimal duration of this treatment prior to the surgical intervention. Recent studies have reported a total remission rate after conservative management between $70 \%$ and $90 \% \%^{6,7}$.

The optimal duration of the conservative management represent a subject of intense debate. Retrospective studies and databases have demonstrated the fact that prolonging this type of therapy, posponing the surgical intervention, may increase the morbidity and mortality rates ${ }^{8,9}$. There is no general recommendation on this matter, but, the majority of the authors support the idea of a 72 hours safe and efficient interval, prolonging this interval increasing the risk of complications, such as kidney failure, electrolitic imbalances, malnutrition and aspiration pneumonia ${ }^{8}$. Prolonging the 72-hour interval for patients with no signs of clinical deterioration with functional nasogastric tube, represent a controversial topic.
The results of the present study, however, demonstrated the possibility of extending the conservative management over 72 hours, the average duration being about 7 days, the maximum duration being 14 days for 3 patients who responded favorably to this type of treatment. These data support the idea of extending the duration of the conservative management beyond the maximum recommended by the medical literature, at the moment, without affecting the safety of patients.

Taking into consideration the clinical, paraclinical and imagistic variables, a less complicated stage can be observed in patients receiving conservative treatment than those undergoing surgery, explaining the longer duration of the conservative management in the present study, compared to that reported by recent literature, thus, suggesting the possibility of prolonging the non-surgical therapy only after carefully selecting the patients.

The statistical significance of the present study is limited by its design (retrospective), by the reduced number of cases and the short follow- up interval, prospective studies on a large population being required in order to validate the hypotheses resulted from this study.

\section{CONCLUSIONS}

Surgery is not the only therapeutic solution in case of intestinal obstruction secondary to postoperative peritoneal adhesions.

The presence of peritoneal signs, fever and leukocytosis support early surgery, conservative management being indicated in the absence of these signs.

The recommended median interval of conservative treatment is 72 hours.

Under strict clinical and paraclinical monitoring and in the absence of suggestive signs of complications, the duration of the conservative management can be safely extended up to 7-14 days, before deciding on the surgical treatment.

\section{Compliance with ethics requirements:}

The authors declare no conflict of interest regarding this article. The authors declare that all the procedures and experiments of this study respect the ethical standards in the Helsinki Declaration of 1975 , as revised in 2008(5), as well as the national law. Informed consent was obtained from all the patients included in the study. 


\section{References}

1. Goyal SK, Chhabra UK, Bansal SK, Choudhary D, Goyal PK, Singal G. Intestinal obstruction - A retrospective study of 150 cases. IAIM, 2016; 3(3): 29-34

2. Springer JE, Bailey JG, Davis PJB, Johnson PM. Management and outcomes of small bowel obstruction in older adult patients: a prospective cohort study. Canadian Journal of Surgery. 2014;57(6):379-384. doi:10.1503/cjs.029513

3. Ten Broek RPG, Krielen P, Di Saverio S et al. Bologna guidelines for diagnosis and management of adhesive small bowel obstruction (ASBO): 2017 update of the evidence-based guidelines from the world society of emergency surgery ASBO working group. World J Emerg Surg. 2018 Jun 19;13:24. doi: 10.1186/ s13017-018-0185-2. eCollection 2018.

4. Mazuji MK, Kalambaheti K, Pawar B. Prevention of adhesions with polyvinylpyrrolidone. Preliminary report. Arch Surg. 1964:89(6):1011-1015

5. Ellis H, Moran BJ, Thompson JN, Parker MC, Wilson MS, Menzies D, McGuire A, Lower AM, Hawthorn RJS, O'Brien F, Buchan
S, Crowe AM. Adhesion-related hospital readmissions after abdominal and pelvic surgery: a retrospective cohort study. Lancet 1999; 353: 1476-1480

6. Fazel MZ, Jamieson RW, Watson CJ. Long-term follow-up of the use of the Jones, intestinal tube in adhesive small bowel obstruction. Ann R Coll Surg Engl. 2009;91(1):50-4.

7. Schraufnagel D, Rajaee S, Millham FH. How many sunsets? Timing of surgery in adhesive small bowel obstruction: a study of the nationwide inpatient sample. J Trauma Acute Care Surg. 2013;74(1):181-7.

8. Keenan JE, Turley RS, McCoy CC, Migaly J, Shapiro ML, Scarborough JE. Trials of nonoperative management exceeding 3 days are associated with increased morbidity in patients undergoing surgery for uncomplicated adhesive small bowel obstruction. J Trauma Acute Care Surg. 2014;76(6):1367-72.

9. Fevang BT, Jensen D, Svanes K, Viste A. Early operation or conservative management of patients with small bowel obstruction? Eur J Surg. 2002;168(8-9):475-81. 